Western University Scholarship@Western

Department of Economics Research Reports

Economics Working Papers Archive

1973

\title{
The Capital Bias of DREE Incentives
}

Robert S. Woodward

Follow this and additional works at: https://ir.lib.uwo.ca/economicsresrpt

Part of the Economics Commons

Citation of this paper:

Woodward, Robert S.. "The Capital Bias of DREE Incentives." Department of Economics Research Reports, 7315. London, ON:

Department of Economics, University of Western Ontario (1973). 


\section{RESEARCH REPORT 7315}

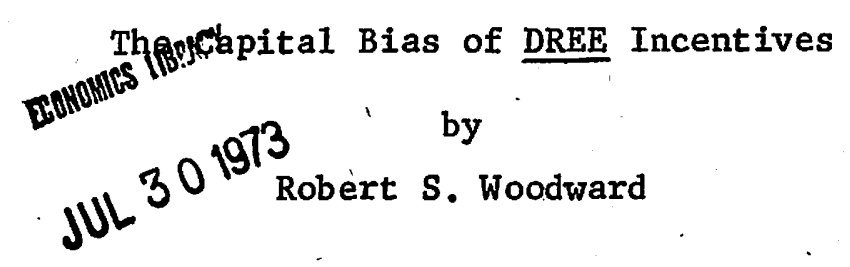

Ju1y, 1973 
THE CAPITAL BIAS OF DREE INCENTIVES *

Robert s. Woodward ${ }^{t}$

\section{Introduction}

This paper argues that the capital bias of the regional industrial subsidies offered by the Department of Regional Economic Expansion (DREE) under the Regional Development Incentives Act (RDIA) is inconsistent with the Department's primary objective--increasing employment in depressed regions. In section II the argument briefly reviews the DREE program goals and defines capital-biased subsidies. Section III documents the capital bias of the three regional maximum formulas. Section IV demonstrates the importance of the capital constraint by developing the isocost frontier for firms seeking the maximum grants in the Atlantic Provinces. While the grants received must be less than the maximums defined by the formulas and constraints, the actual size and bias of the subsidies are determined by DREE officials and represented as DREE offers. The bias of the offers, which is likely to be independent of all upper limits, is examined in section V. And in section VI the taxation laws are shown to lower the government's net payment without affecting the bias except when the grant equals or is greater than the firm's fixed capital, in which case taxation shifts the bias towards labour.

\section{DREE Goals and Capital Bias}

That increased employment in depressed areas is the primary objective of the DREE incentives is clear from the original RDIA and the DREE staff 
papers. The Act was intended "an Act to provide incentives for the development of productive employment opportunities in regions of Canada determined to require special measures..."1 Further, regions were designated as eligible for DREE incentives if "existing opportunities for productive employment in the region are exceptionally inadequate." 2 Francis and Pillai confirm the Department's raison d'etre as "the provision of appropriate programs to stimulate new productive employment opportunities." 3

A slight change in the presentation of DREE's goals in a recently published staff paper affirms that employment is the primary objective but implicitly (and incorrectly) suggests that no conflict exists between investment subsidies and increased employment as the primary goal. In this paper DREE's primary goal is given as increasing manufacturing job opportunities in designated regions "by stimulating private investment." 4 Goals which would be consistent with a capital bias such as higher wages and industrialization are 1 isted as secondary.

The problem with attempting to increase employment by "stimulating private investment" (or financing part of the plant, machinery and equipment expenses) is that most firms can substitute such capital for labour in their production process. In particular, most firms which find that they will be eligible for a larger grant if they increase their capital-1abour ratio are likely to include a larger than necessary amount of capital in their application. Further, most firms which have their machinery costs reduced substantially more than their labour costs are likely to expand their output by purchasing a proportionately greater increment of machinery and equipment than of labour.

Such output expansions with larger-than-normal capital components are likely to occur if the incentives are capital biased. Precisely, any 
production subsidy is capital biased whenever it reduces the price of plant, machinery and equipment proportionately more than the cost of other inputs such as 1abour. Additionally, capital biased subsidies will cause substitutions that increase the capital-1abour ratio whenever the firm's elasticity of substitution is greater than zero and the production function is homothetic. 5 In fact, where the firm's elasticity of substitution is large, a capital-biased subsidy may cause a reduction in the firm's absolute level of employment.

\section{Maximum Grants}

Both the primary and secondary goals are pursued, in part, by offering incentive grants for new industrial activity. Briefly, the grant process is initiated by a firm submitting an application to DREE. Since the application process requires considerable information about the firm's financial and engineering plans, many of the decisions about the production process must be made prior to the application submission. If DREE industrial specialists judge the project viable, worthwhile and in need of aid, DREE makes a grant offer which indicates its willingness to support a percentage of the capital costs and/or pay some amount per employee.

The firm has 90 days to accept DREE's offer and becomes eligible for up to 80 percent of the grant after at least one-half of the assets have been in commercial operation for 30 days. The firm's eligibility to receive the rest of the grant (by achieving the employment and capital targets) is limited to 42 or 39 months according to whether or not the grant included a payment based on the firm's employment. While gross deviations from the original application might jeopardize the firm's eligibility, some substitution between capital and labour and up to 15 percent capital and 
labour overruns may be allowed.

Thus, a firm's actual production decision may be affected by the incentive grant process at two stages--(1) when it makes its application and (2) when it responds to the DREE offer. While the offer may be unrelated to the maximum grant formulas or to the capital or labour constraints, the bias of these upper limits may be important because firms may modify their initial plans to seek eligibility for larger DREE grants. Specifically, the firm's maximum eligibility depends upon the location and type of activity it plans (Table 1 ).

While the capital bias of the modernization or expansion capital subsidy is obvious and needs no further explanation, the bias in the new plant or new product formulas is less apparent. Since in these formulas $\$ 7,000$ equals 35 percent of $\$ 20,000$ (as $\$ 5,000$ is 25 percent of $\$ 20,000$ and $\$ 2,000$ is 10 percent of $\$ 20,000$ ) the capital subsidy will be greater than the labour subsidy if the present value of average wage and salary payments per employee $(W)$ is greater than $\$ 20,000$. Where $W>\$ 20,000$, the maximum formulas in all regions are capital biased.

Accepting that $W$ is determined by the firm's investment horizon and internal rate of discount, as well as by average wage and salary payments, data on $\mathrm{W}$ for the twenty two-digit manufacturing industries (Table 2) suggest that average firms in most industries are likely to have considered the present value of their wage and salary payments greater than $\$ 20,000$. The information also suggests that rising wages between 1965 and 1969 have increased the capital bias of the maximum formulas.

IV. The Capital and Labour Constraints and the Isocost Frontier Although the three formulas determine a firm's maximum eligibility, 
Table 1

Maximum DREE Inicentives

\section{Locat1on}

Region A
(Atlantic Provinces)

Region B

(Standard Designated Regions)
Region C
(Special Designated
Region - southwestern
Quebec and southeastern
Ontario)

Type of Project

\begin{tabular}{c}
$\begin{array}{c}\text { Modernization } \\
\text { or } \\
\text { Expansion }\end{array}$ \\
\hline
\end{tabular}

$30 \%$ of eligible capital costs

$20 \%$ of eligible capital costs

$10 \%$ of eligible capital costs

\author{
New Plant or New \\ Product \\ Expansion
}

$$
\begin{aligned}
& 35 \% \text { of eligible } \\
& \text { capital cost plus } \\
& \$ 7,000 \text { per eligible } \\
& \text { direct job created } \\
& 25 \% \text { of eligible } \\
& \text { capital cost plus } \\
& \$ 5,000 \text { per eligible } \\
& \text { direct job created } \\
& 10 \% \text { of eligible } \\
& \text { capital cost plus } \\
& \$ 2,000 \text { per eligible } \\
& \text { direct job created }
\end{aligned}
$$

Source: "Assessment of the Regional Development Incentives Program," DREE, 4/73, P. 6 . 
Table 2

The Number of Industries with a Present Value of Wages

and Salaries per Employee Greater than $\$ 20,000$

For Alternative Assumptions

Firm's Years

in Operation

Internal Rate of Discount

\begin{tabular}{llll}
\hline $6 \%$ & $10 \%$ & $14 \%$ & $18 \%$
\end{tabular}

$\underline{1965}$

$\begin{array}{lrrrr}4 \text { years } & 6 & 2 & 1 & 1 \\ 6 \text { years } & 17 & 13 & 12 & 6^{\prime} \\ 8 \text { years } & 20 & 17 & 15 & 12 \\ 10 \text { years } & 20 & 20 & 17 & 15\end{array}$

$\underline{1969}$

$\begin{array}{llllr}4 \text { years } & 15 & 12 & 11 & 6 \\ 6 \text { years } & 20 & 17 & 17 & 15 \\ 8 \text { years } & 20 & 20 & 20 & 17 \\ 10 \text { years } & 20 & 20 & 20 & 18\end{array}$

Source: Average wages and salaries are derived from data in Dominion Bureau of Statistics, Canada Yearbook: 1968 and 1972, Ottawa, Queen's Printer.

Note: Total number of industries is 20 . 
the grants are everywhere constrained to less than $\$ 30,000$ per new employee or one-half of the new capital employed, whichever is less. Since graphic representation illustrates how a firm seeking the largest possible grant perceives the combined effect of the maximum formula and the two constraints, the isocost frontier for the combination of the constraints and one maximum formula--that of the Atlantic Provinces--is presented in the following paragraphs.

Consider a firm preparing its application for a DREE grant to assist with a new plant or product. As part of the firm's initial investment decision it must select the most appropriate proportions of plant, machinery and equipment (hereafter called capital $(K))$, labour $(L)$, and working capital (F). Assuming some present value of expenditure (E) over the life of the capital and where $K, L$ and $F$ are independent production inputs, the firm's isocost function may be written

$$
\mathrm{K}+\mathrm{WL}+\mathrm{F}=\mathrm{E}
$$

where

$$
\begin{aligned}
& \mathrm{K}=\text { the value of new plant, machinery and equipment, which is } \\
& \text { assumed to equal "eligible capital costs" and to have a } \\
& \text { predetermined lifetime after which it has no scrap value; } \\
& \mathrm{W}=\text { the present value of wage and salary payments per employee } \\
& \text { over the life of the capital } \mathrm{K} \text {; } \\
& \mathrm{L}=\text { employment during the life of the capital } \mathrm{K} \text {, which is assumed } \\
& \text { constant at all times; } \\
& \mathrm{F}=\text { the present value of working capital necessary over the life } \\
& \text { of the capital } \mathrm{K} \text {; and }
\end{aligned}
$$




\section{$-8-$}

$E=$ the present value of the firm's expenditure on $F, K$ and $L$ over the life of the capital $K$.

In the Atlantic Provinces, where the maximum formula would reduce the price of capital by 35 percent and 1 abour by $\$ 7,000$ per job, the amounts of capital and labour that the given expenditure (E) could purchase would be given by the isocost equation

$$
.65 K+(W-\$ 7,000) L+F=E
$$

Graphically, if the plane MNO (Figure 1) represents equation (1), then MPQ represents the expanded isocost frontier of equation (2).

The labour constraint restricts the firm's grant eligibility to $\$ 30,000$ per job and defines an isocost frontier equal to the combinations of capital, labour and working capital which could be purchased by an expenditure $E$ if $W$ were reduced by $\$ 30,000$ (equation ( 3 ) and MNT in Figure 2):

$$
K+(W-\$ 30,000) L+F=E \text {. }
$$

The capital constraint restricts the firm's eligibility to a grant not greater than 50 percent of $(K+F)$ and defines an isocost frontier equal to the amounts of $K, L$ and $F$ which the firm could buy with $E$ if the price of $\mathrm{K}$ and $\mathrm{F}$ were reduced by 50 percent (equation (4) and RSO in Figure 2).

$$
.5 \mathrm{~K}+\mathrm{WL}+.5 \mathrm{~F}=\mathrm{E} \text {. }
$$

Considering the combined effects of the Atlantic Province maximum formula and the capital and labour constraints, the resulting isocost frontier is composed of the sections of the planes MPQ, MNT or RSO which are lowest 


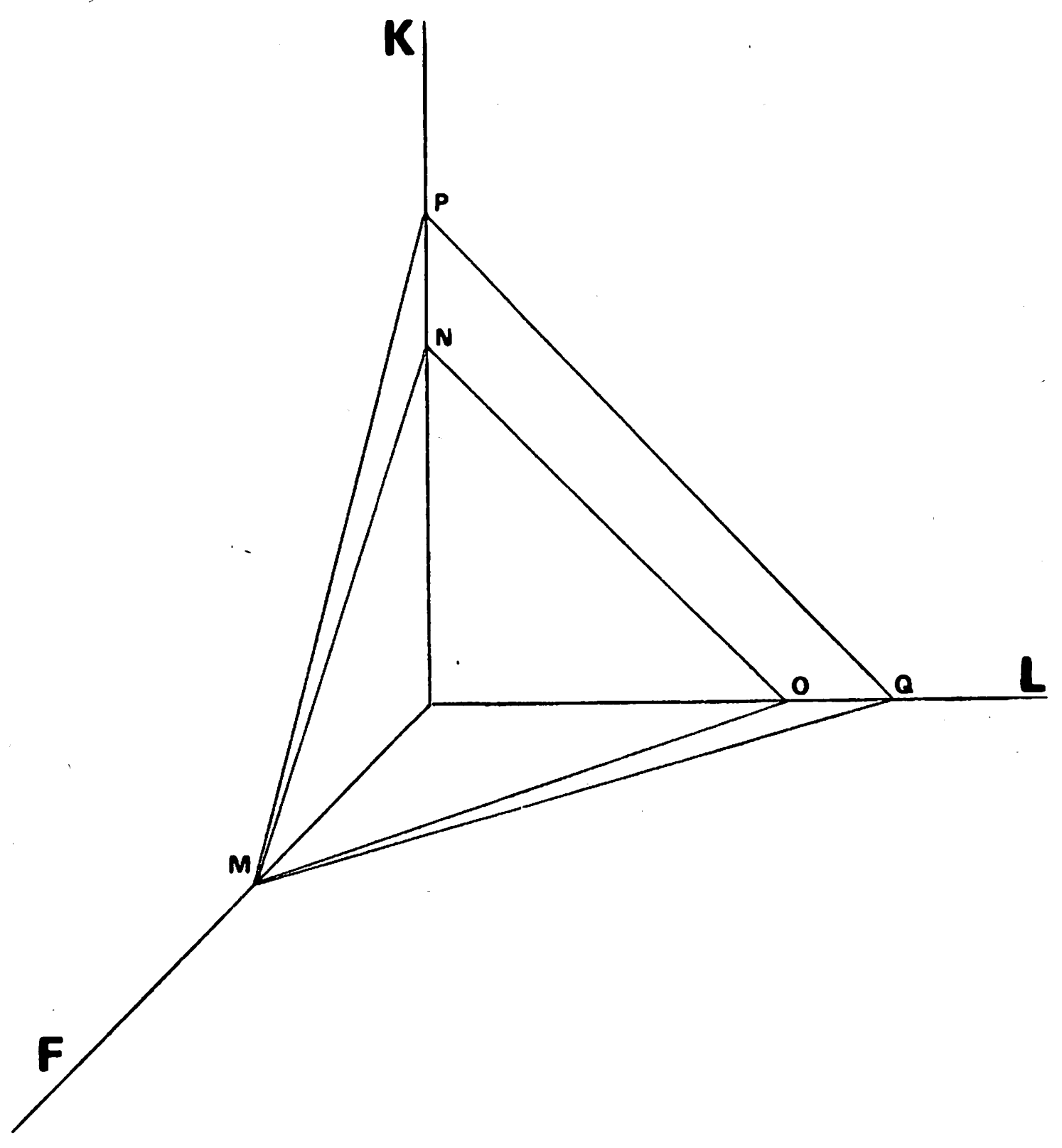

Figure 1

An Isocost Plane Before and After the Atlantic Province Maximum Subsidy 
$-10-$

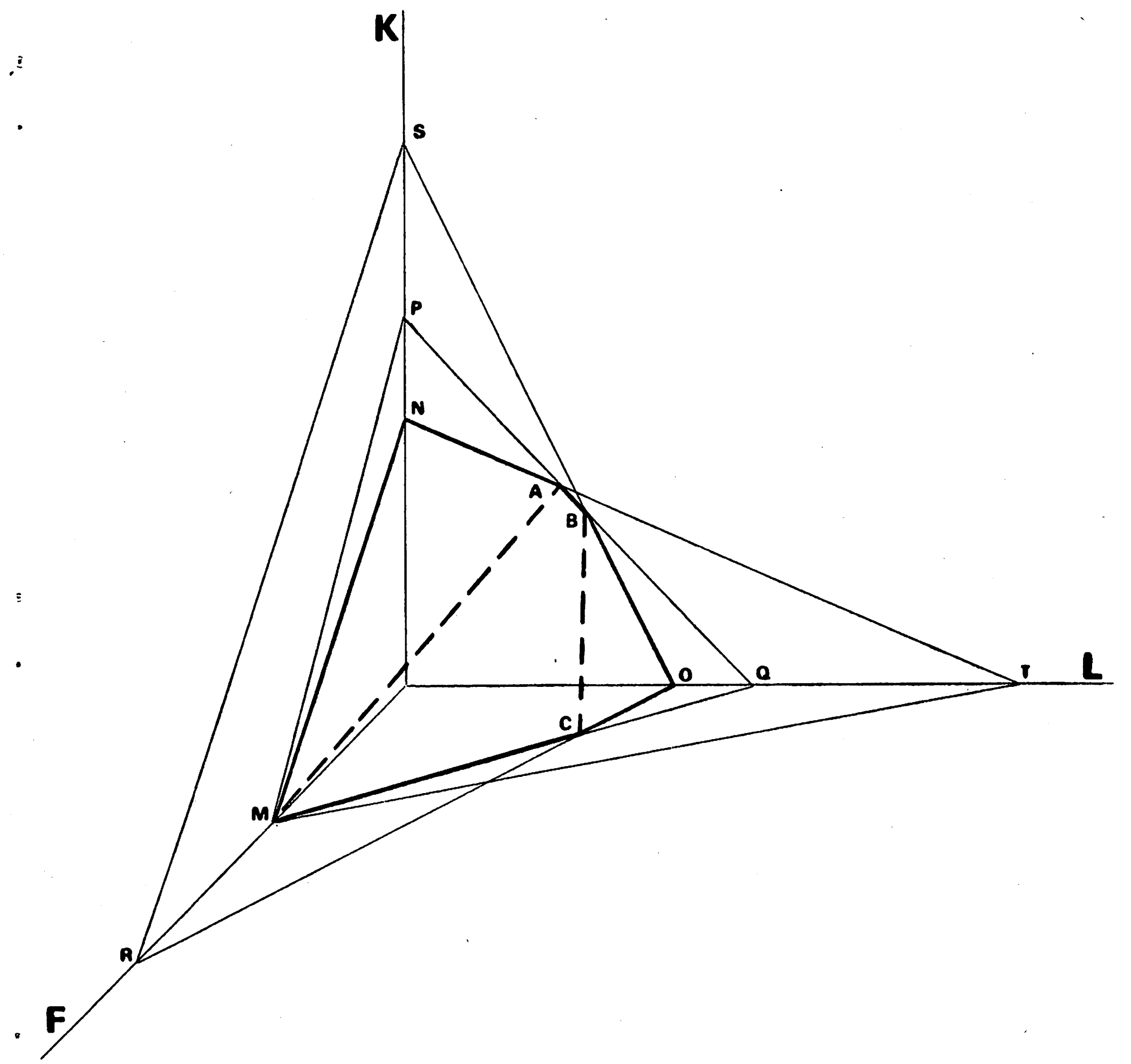

Figure 2

The Isocost Planes of the Capital and Labour Constraints 
or closest to the origin. Since MPQ intersects MNT along line MA and intersects RSO along the line $\mathrm{BC}$, the resultant isocost frontier is defined by the planes MAN, MABC and $C B O$ (Figure 3 ).

Calculations using information for each of 87 manufacturing industries indicate that the average firms in 69 industries employ sufficient labour to be on the capital constraint $\mathrm{CBO} .^{6}$ Additionally, average firms in 30 industries and in 1 industry would be on the capital constraint rather than the maximum formula in Regions B and C, respectively, of Table 1. In contrast, average firms in only 2, 1 and 0 industries would be subject to the labour constraints in Regions A, B and C respectively.

\section{DREE Offers}

The firm's reaction to the DREE offer represents a second opportunity for the firm to modify its production process. Although an analysis of all DREE's offers is impossible, a tabulation of the bias for offers accepted from November 1972 through April 1973 (Table 3) is taken as an indication of the program's general pattern. Since the large majority of offers involve a capital cost reduction greater than the reduction of the present value of wages and salaries per employee, most offers are capital biased.

Nevertheless, evidence from a simple regression analysis suggests that DREE has made offers such that the magnitude of the bias has decreased with more capital intensive and larger firms. For the 168 offers between November 1972 and April 1973 which included an employment component, the ratio of the capital offer to the labour offer was regressed with the capital-1abour ratio of the firm and the size of the project as measured by capita1? (equation (5)). 


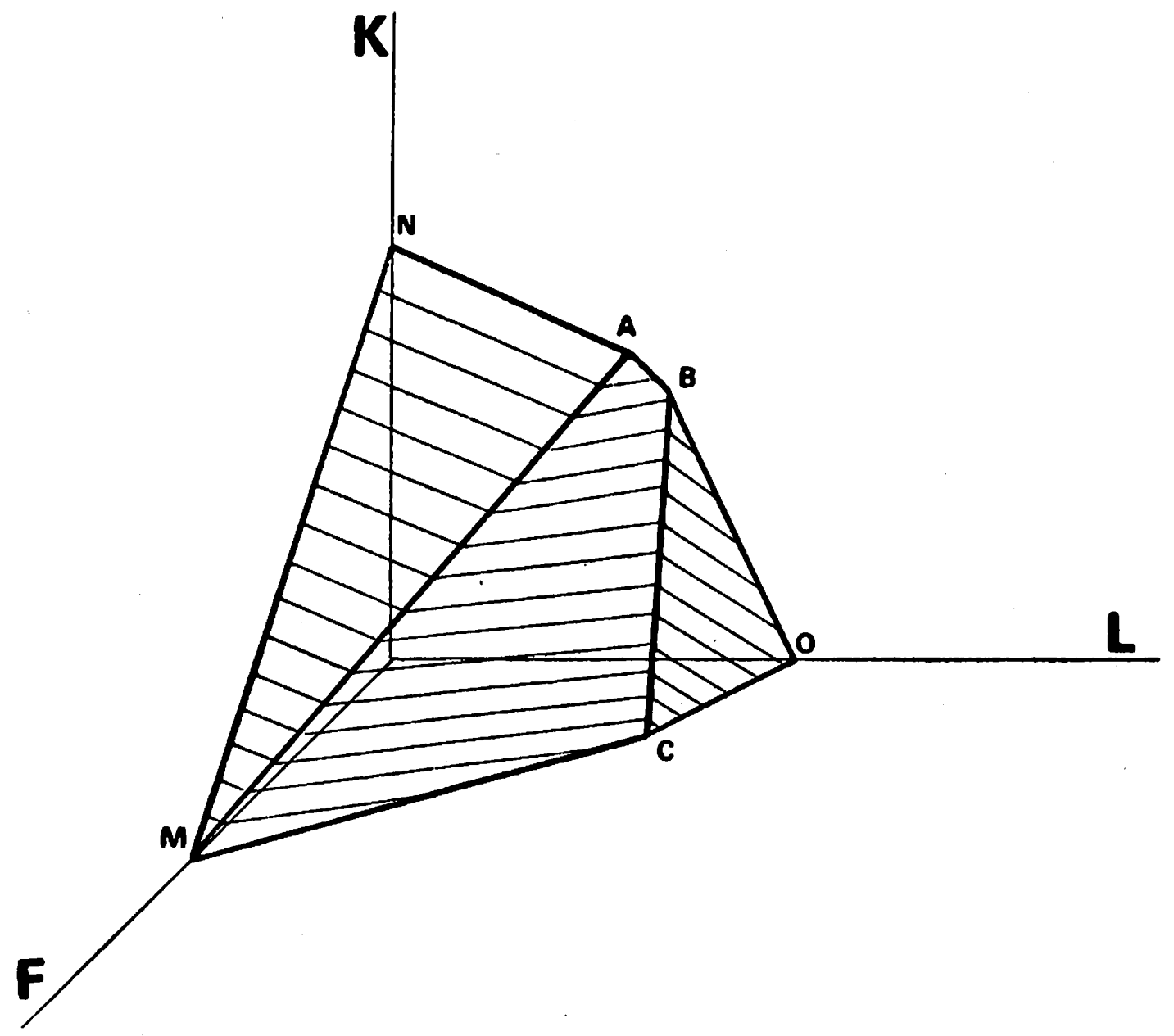

Figure 3

The Resulting Isocost Frontier 
Table 3

Percentage of Offers with a Positive Capital Bias

For A1ternative Assumption

Firm's Years

in Operation

4 years

6 years

8 years

10 years
$86 \%$

$95 \%$

$98 \%$

$100 \%$
Internal Rate of Discount

\begin{tabular}{rrrr}
\hline $6 \%$ & $10 \%$ & $14 \%$ & $18 \%$ \\
$86 \%$ & $82 \%$ & $80 \%$ & $76 \%$ \\
$95 \%$ & $94 \%$ & $90 \%$ & $86 \%$ \\
$98 \%$ & $95 \%$ & $95 \%$ & $91 \%$ \\
$100 \%$ & $98 \%$ & $95 \%$ & $94 \%$
\end{tabular}

Data Sources: New P1ant or Product Offers; Department of Regional Economic Expansion, "Accepted Offers," November 1972 through April 1973.

Average Wage and Salaries: Car1 Dudley (forthcoming) 


$$
\begin{aligned}
& \text { LNKLOFF }=3.59-\frac{.27 \text { LNKLRAT }}{(.06)}=\frac{.15 \text { LNK }}{(.04)} \\
& \begin{array}{c}
\mathrm{R}^{2}=.27 \\
\mathrm{~F}=30.0 \\
\text { with }(2,165) \text { d.f. }
\end{array}
\end{aligned}
$$

where

LNKLOFF $=$ the natural $\log$ of the ratio of the capital offer (in percent of eligible capital) to the labour offer (in thousands of dollars);

LNKLRAT $=$ the natural $\log$ of the ratio of eligible capital expenses (in thousands of do1lars) to total expected employment;

LNK = the natural $\log$ of the eligible capital expenses (in thousands of dollars).

The numbers in parentheses are the standard errors of the coefficients. All coefficients are significant at the 1 percent level.

Since the coefficient on LNKLRAT is negative and highly significant, an increase in the capital-labour ratio correlates with a decrease in the capital offer-1abour offer ratio. Since the coefficient on LNK is negative and highly significant, an increase in eligible capital correlates with a decrease in the capital offer-1abour offer ratio. Thus while the large majority of offers embody a positive capital bias, the magnitude of that bias is reduced (or shifted towards favouring labour) for capital intensive and for large firms. Clearly, if the bias is to be systematically determined by size and capital content, reducing the capital bias for large firms is more consistant with DREE's employment goals than reducing it for small firms. 
VI. Tax Treatment

While DREE grants are not taxed as corporate income, 8 administrative regulations disallow capital depreciation of plant, machinery, and equipment of an amount equal to the DREE grant regardless of its capital or labour content. 9 Thus, where the grant (G) is less than the firm's capital (K), the grant is indirectly taxed since corporate income, which would otherwise be tax free because of capital depreciation, is taxed as income. If $G<K$, taxation reduces the net government subsidy but leaves the bias of the offer unaffected. For example, if an offer were made for 30 percent of capital and $\$ 1,000$ per job (an offer with substantial capital bias for most firms), a 40 percent corporate tax rate would reduce the after-tax-grant to 18 percent of capital and $\$ 600$ per job (a formula which reflects equal distortion of relative prices and thus equal capital bias).

If the grant is at least as large as the capital stock, the capital bias will be shifted in labour's favour. As an example, consider a firm with an offer of 25 percent of capital and \$5,000 per employee which happens to exactly equal its investment in plant, machinery and equipment (K),

$$
.25 \mathrm{~K}+\$ 5,000 \mathrm{~L}=\mathrm{K} \text {. }
$$

Assuming a corporate income tax rate of 40 percent, the firm receives an after-tax-grant equal to 15 percent of capital plus $\$ 3,000$ per employee on $\mathrm{K}$ and $\mathrm{L}$ included in equation (6). However, if the company considers hiring one more employee, it will receive $\$ 5,000$ after taxes since the additional grant cannot disallow any additional depreciation. But if the firm considers an extra dollar of investment, depreciable capital will increase by more than the grant so that the after-tax-grant to the firm remains equal to 15 
percent of capital. Thus where $G \geqq K$, whatever bias existed will be shifted to favour labour.

A calculation of the number of firms which are likely to receive grants greater than their capital is possible for the six months of accepted DREE offers examined above. Based on that information and making the assumption that the expected capital and labour figures are accurate, 4 of 349 firms received offers for grants greater than their capital. Only these few firms are likely to receive more favourable tax treatment and be subject to a diminished capital bias.

VII. Conclusion

In conclusion, the capital bias of DREE's maximum incentive formula, of the capital constraint and of the majority of offers is inconsistent with the Department's primary objective--employment. The inconsistency occurs because a capital bias implies that the designated regions' extra employment attributable to the grant program is less and investment more than would have occurred if the incentives had been neutral or 1 abour biased.

In fact, employment increases attributable to capital-biased subsidies occur only because most firms' production functions do not allow a great amount of substitution. If capital were highly substitutable for 1abour, investment subsidies would reduce employment regardless of the output expansion.

Two additional implications of the capital bias follow. First, the cost of each new job in the designated regions attributable to the DREE incentives has been increased by the bias since the number of jobs has decreased. Second, to the extent that the bias caused extra machinery and equipment to be purchased from either the more industrial regions in 
Canada or the rest of the world, areas such as Toronto or Detroit may have their employment increased by the bias. 
* This research was financed in part by a grant from Canada Council. The author would like to thank Kevin Collins, Mark Frankena, Tom Courchene, and Gordon Davies for their comments on earlier drafts of this paper and Carl Dudley for his data and suggestions. Remaining errors are the author's responsibility.

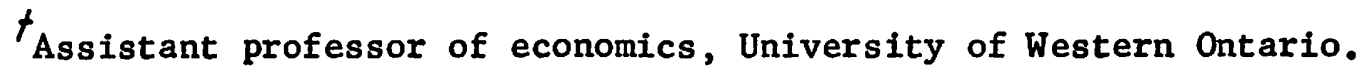

$1_{\text {Canada }}(1970,6543)$.

${ }^{2}$ Canada $(1970,6544)$.

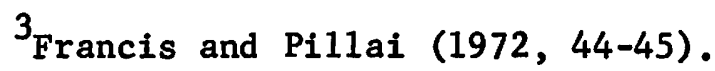

${ }^{4}$ Canad a $(1973,3)$.

${ }^{5} \mathrm{~A}$ homothetic function is a monotonic transformation of a positive homogeneous function (Chipman $[1965,690]$ ).

6 Data on capital, employment and working capital are from the data file and calculations of Dudley (forthcoming).

7 Regressions with the project's scale measured by employment gave similar results.

${ }^{8}$ Canada $(1970,6550)$

${ }^{9}$ Canada $(1971,5)$. 
Canada, Revised Statutes of Canada, VI (1970), Chapter R-3.

Canada, Department of National Revenue, Taxation, "Income Tax Act: Government Grants to Industry," Interpretation Bulletin Serial Number IT-49, December 29, 1971.

Canada, Department of Regional Economic Expansion, "Assessment of the Regional Development Incentives Program," one of a series of Staff Papers prepared by the Federal Department of Regional Economic Expansion, April 1973.

Chipman, J. S. "A Survey of the Theory of International Trade: Part 2, The Neo-Classical Theory," Econometrica, 33 (1965), 685-760.

Dudley, C. "A Theoretical Analysis of the Effect of Capital Subsidies as an Incentive to Modify the Locational Choices of New Business Activity," Ph.D. dissertation, University of California at Berkeley, forthcoining.

Francis, J. P., and Pillai, N. G. "Regional Development and Regional Policy: Some Issues and Recent Canadian Experience," Regiona1 Economic Expansion Canada, February 1972. 